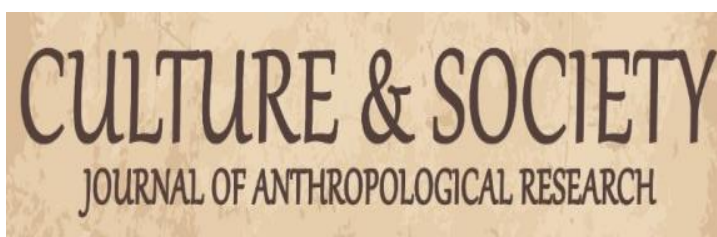

Culture \& Society: Journal of Anthropological Research

VOL. 2 NO. 3 MARET 2021

http://culture.ppj.unp.ac.id

Email: culture@ppj.unp.ac.id

ISSN: 2686-343X (E-ISSN) 2686-3421 (P-ISSN)

DOI: https://doi.org/10.24036/csjar.v2i3.67

\title{
Motivasi Anak Nagari Mengikuti Silek Kumango
}

\author{
Lia Amelia ${ }^{1}$, Rio Putra Winanda ${ }^{2}$ \\ ${ }^{1}$ Universitas Negeri Padang \\ ${ }^{2}$ Universitas Andalas
}

Email: liaamelia@fis.unp.ac.id, rionanda.rn96@gmail.com

\begin{abstract}
Abstrak
Permainan tradisional daerah atau permainan anak nagari yaitu silek merupakan bentuk dari sebuah kesenian yang memiliki nilai keindahan bagi penikmatnya. Di era modernisasi, masih ada generasi muda yang mempelajari dan menekuni Silek Kumango. Penelitian ini dilakukan di Nagari Kumango Kabupaten Tanah Datar, Sumatera Barat. Pendekatan penelitian kualitatif, dengan metode pengumpulan data antara lain: (1) wawancara (interview), dengan 18 informan yang terdiri dari Guru Sasian Silek Kumango, Guru Tuo/penasehat Silek Kumango, pelajar/ mahasiswa, Tokoh Adat Nagari Kumango, dan Orang tua Persi Silek Kumango; (2) pengamatan (Observasi) pada pelaksanaan permainan anak Silek Kumango; dan (3) studi kepustakaan dalam bentuk artikel, laporan penelitian terdahulu berserta sumber bacaan lainnya yang berkaitan dengan penelitian tentang Silek Kumango. Hasil penelitian menunjukkan bahwa motivasi para generasi muda ingin mempelajari Silek Kumango selain untuk pelestarian budaya, juga karena rasa ingin tahu terhadap Silek Kumango, rasa aman dan keinginan untuk berprestasi serta dipengaruhi oleh lingkungan sosial.
\end{abstract}

Kata kunci: Motivasi, Permainan tradisional, Silek Kumango

\section{Abstract}

Traditional regional games or games for the children of the Nagari, namely Silek, are a form of ant that has aesthetic value for the audience. In the modernization era, there are still young generations who study and pursue Silek Kumango. This research was carried out in Kumango Nagari, Tanah Datar Regency, West Sumatera. Qualitative research approaches with data collection methods include (1) interviews with 8 informants who are categorized as Sasian Teacher Silek Kumango, Tuo Teacher Silek Kumango, Trraditional Figure Nagari Kumango; (2) Observation on the the implementation of children's games Silek Kumango; and (3) literature study in the form of articles, previous research reports along with other sources of reading related to research Silek Kumango. The results show that the motivation of the younger generation to learn Silek Kumango is not only for cultural preservation, but also because all silek movements are very easy to implement. Through Silek Kumango, the younger generation is taught martial arts and how to behave properly according to Islamic teachings and Minangkabau customs.

Kata kunci: Existence, Traditional game, Silek Kumango.

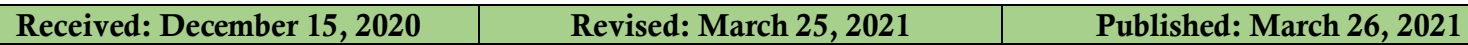

Culture \& Society: Journal of Anthropological Research Vol. 2, No. 3, Th. 2021 


\section{Pendahuluan}

Suku bangsa di Indonesia memiliki berbagai tradisi yang diwariskan secara turun-temurun. Tradisi itu terwujud dalam bentuk upacara tradisional, hingga permainan rakyat tradisional. Keberadaan permainan tradisional atau dalam masyarakat Minangkabau mengenalnya dengan nama permainan anak nagari, merupakan wujud dari kebudayaan yang menjadikan nilai-nilai budaya dapat diteruskan dari generasi satu ke generasi berikutnya.

Bagi generasi tua suku bangsa Minangkabau, terdapat berbagai bentuk permainan anak nagari pada tiap daerahnya. Salah satu contohnya adalah permainan anak nagari yang dikenal dengan nama silat atau silek. Saat ini silek masih banyak dipelajari oleh pemuda dan remaja, bahkan sudah menjadi kebanggaan generasi muda Minangkabau jika para pemuda dan remaja menguasai silek Minang tersebut. Menurut Nasir, silek terdiri dari dua kata yaitu Pencak dan Silat. Pencak bermakna permainan sedangkan Silat adalah seni beladiri. Jadi disaat kita mempelajari pencak silat terdapat unsur seni dan beladiri. Seni terlihat pada pergerakannya, sedangkan beladiri terlihat pada unsur-unsur dalam gerakan itu (Saputra, 2011).

Silek di Minang Kabau mempunyai beberapa aliran yang berkembang sesuai dengan daerah asalnya. Aliran silek cukup banyak antara lain "Silek Lintau berasal dari Lintau, silek Kumango berasal dari nagari Kumango, kedua aliran ini berasal dari Tanah datar. Kemudian ada Silek Balubuih dari Limo Puluah Koto, dan Silek Pauah dari Padang. Pada penelitian ini akan difokuskan kepada silek Kumango yang berasal dari Nagari Kumango Tanah Datar. Seperti yang telah diketahui bersama bahwa silek Kumango merupakan silek di Minangkabau yang telah dikenal dunia internasional. Pada masa sekarang keberadaan silek Kumango tersebut memang belum memudar dan ditinggalkan oleh para masyarakat penikmatnya (Saputra, 2011).

Permainan anak nagari terfokus pada silek itu sebenarnya sarat akan filosofi hidup. Pada setiap geraknya terdapat pesan dan ajaran budi pekerti, moral dan perilaku, di antaranya ada yang menuntut ketangkasan, kekuatan fisik, kecerdasan dan kecerdikan, kecepatan dan ketepatan, kreatifitas dan imajinatif, keberanian, kepemimpinan dan rasa tanggung jawab, baik itu kepada diri sendiri maupun kepada kelompok (jika permainan itu dilakukan secara berkelompok atau beramai-ramai).

Silek Kumango adalah bagian dari permainan anak nagari atau permainan rakyat tradisional yang merupakan bentuk dari sebuah kesenian. Hal demikian dikatakan karena memang silek Kumango memiliki nilai-nilai keindahan tersendiri bagi setiap penikmatnya. Permainan rakyat tradisional merupakan salah satu manifestasi tingkah laku manusia yang dilakukan dalam kegiatan fisik dan mental sebagai bagian dari kebudayaan bangsa di mana setiap suku bangsa yang mempunyai permainan rakyat tersendiri (Yunus, 1980).

Realitas yang sangat memprihatinkan saat ini bahwa permainan anak tradisional sudah mengalami penggerusan keberadaan oleh kian maraknya permainan-permainan modern yang sejatinya tidak berakar dari identitas budaya lokal yang selama ini menjadi warisan dari khasanah budaya nusantara dari nenek moyang atau leluhur bangsa Indonesia (Danandjaja. J, 2002). Kroeber dalam Dharmamulya berpendapat bahwa seandainya nenek moyang manusia tidak mempunyai gairah bermain, barangkali kita akan mewarisi kebudayaan yang miskin akan keindahan ataupun miskin keilmuan (Dhamarmulya, 1993).

Pengaruh modernisasi saat sekarang ini yang mau tidak mau akan dan telah diterima oleh sebahagian besar masyarakat Indonesia dan Minangkabau khususnya memberikan konsekuensi logis terhadap keberadaan permainan anak nagari. Permainan baru saat ini yang dimunculkan dari adanya arus modernisasi telah merangsek jauh dalam kehidupan generasi muda, selain mempunyai indikasi akan semakin menjauhkan generasi muda dari hubungan-hubungan perkawanan yang personal ke impersonal, juga menyebabkan menipisnya orientasi wawasan generasi muda dari komunalistik ke individualistik (Sumirtarsih, 2008). Permainan tradisional anak-anak di Jawa misalnya, dikatakan mengandung nilai-nilai budaya tertentu serta mempunyai fungsi melatih pemainnya melakukan hal-hal yang akan penting nantinya bagi

Culture \& Society: Journal of Anthropological Research Vol. 2, No. 3, Th. 2021 
kehidupan mereka di tengah masyarakat, seperti misalnya melatih kecakapan berfikir, melatih tidak cengeng, melatih keberanian, melatih bersikap jujur dan sportif dan sebagainya (Tashadi, 1993).

Permainan anak nagari terdapat di seluruh pelosok Minangkabau ini, masih ada daerah yang mempertahankan atau melestarikan permainan anak nagari dalam kesehariannya. Contohnya saja di Nagari Kumango, Tanah Data, merupakan salah satu daerah di Minangkabau yang memiliki beberapa jenis permainan anak nagari yang tidak dimiliki oleh daerah lainnya, diantaranya pacu jawi, silek Kumango, dabuih (menari dengan menggunakan senjata tajam, api dan kaca) dan lukah gilo. Ada juga atraksi seni tari di atas telur, tari di atas pepaya dan tari di atas air (Saputra, 2011).

Penelitian ini menggunakan metode etnografi dalam pelaksanaannya di lapangan. sesuai dengan maksud penelitian etnografi itu sendiri adalah untuk melukiskan realitas dan menyajikan hasil analisis melalui retorik yang tepat (Ahimsa-Putra, 2009) (Koentjaraningrat, 1980). Hal ini juga didasarkan karena masih kurangnya referensi dan informasi tentang keberagaman bentuk dan jenis permainan anak nagari Minangkabau dan dapat dijadikan sebagai pedoman untuk mengingat dan melestarikan kembali permainan anak nagari Minangkabau.

Penelitian tentang Silek Kumango telah banyak dilakukan, diantaranya yang berfokus pada kearifan lokal dan koreografi (Saputra,2011; Sukri, 2019; Krisnawardi \& Ismar, 2017). Terdapat beberapa fungsi dan simbol yang menunjukkan kearifan lokal dalam Silek Kumango terwujud dalam proses, kontrol, dan gerak dalam silek ini (Saputra, 2011). Silek Kumango mengaktualisaikan ide dan gagasan didalam koreografi Tonggak Raso (Sukri, 2019). Proses penciptaan koreografi gaulik kumango yang terinspirasi dari Silek Kumango (Krisnawardi \& Ismar, 2017).

Berbeda dengan studi sebelumnya yang berfokus pada kearifan lokal dan koreografi pada Silek Kumango, penelitian ini berfokus pada Silek Kumango sebagai permainan anak nagari/ permainan tradisional (folklor sebagian lisan). Sudah selayaknya kebertahanannya tetap dijaga dan dilestarikan oleh generasi muda saat ini. Untuk mengurangi atau mengantisipasi hal ini perlu adanya penelitian dalam bentuk mengidentifikasi berbagai jenis permainan anak nagari Minangkabau khususnya di Nagari Kumango, Tanah Datar yang dikenal sebagai Luhak Nan Tuo Ranah Minang.

\section{Metode Penelitian}

Penelitian dilakukan di Nagari Kumango Tanah Datar. Nagari Kumango dikenal sebagai salah satu daerah yang masih kuat mempertahankan permainan anak nagari Silek Kumango. Tanah Datar. Informan dalam penelitian ini sebanyak 8 orang yang terdiri dari Guru Sasian Silek Kumango, Guru Tuo/penasehat Silek Kumango, pelajar/ mahasiswa, Tokoh Adat Nagari Kumango, dan orang tua Persi Silek Kumango.

Tabel. 1 Karakteristik Informan

\begin{tabular}{ccll}
\hline No. & Nama & Umur & \multicolumn{1}{c}{ Pekerjaan } \\
\hline 1 & RM & 30 tahun & Guru Sasian Silek Kumango \\
\hline 2 & US & 63 tahun & Tokoh Adat Nagari Kumango \\
\hline 3 & ZM & 78 tahun & Guru Tuo/ Penasehat Silek Kumango \\
\hline 4 & DA & 22 tahun & Mahasiswa \\
\hline 5 & FJ & 18 tahun & Pelajar \\
\hline 6 & RK & 16 tahun & Pelajar \\
\hline 7 & AS & 54 tahun & PNS \\
\hline 8 & DV & 16 tahun & Pelajar \\
\hline 9 & NY & 52 tahun & Ibu Rumah Tangga \\
\hline
\end{tabular}

Culture \& Society: Journal of Anthropological Research Vol. 2, No. 3, Th. 2021 
Penelitian ini menggunakan pendekatan penelitian kualitatif dengan metode etnografi. Pengamatan dilakukan pada pelaksanaan dan kebertahanan permainan anak nagari yang ada di Nagari Kumango dan wawancara yang digunakan adalah wawancara mendalam untuk mengetahui pengetahuan masyarakat Nagari Kumango Tanah Datar terhadap Silek Kumango permainan anak nagari, dan untuk mengetahui alasan para generasi muda antusias dalam mempelajari Silek Kumango.

\section{Hasil dan Pembahasan}

\section{Silek Kumango Sebagai Permainan Anak Nagari}

Berikut ini merupakan hasil dari penelitian yang didapatkan dari wawancara dengan informan. Sejarah dan proses pelaksanaan Silek Kumango adalah hasil wawancara dengan ZM (78 tahun), RM (30 tahun), dan US (68 tahun) alasan generasi muda mempelajari Silek Kumango hasil wawancara dengan beberapa pesesta Silek Kumango.

\section{Sejarah Silek Kumango Sebagai Permainan Anak Nagari}

Kelahiran Silek Kumango adalah perwujudan dari keinginan dan tekat yang keras bagi penyempurnaan silat-silat yang telah lebih dahulu berkembang. Rancangan dan ramuan silek Kumango ini dilakukan sendiri oleh pendiri aliran ini yaitu (alm) Abdurrahman dengan gelar Datuk Majo Indo atau yang lebih dikenal dengan Syekh Abdurrahman Al-Kholidi atau yang lazim dipanggil dengan panggilan Beliau Kumango. Pada masa muda Beliau Kumango mempunyai dorongan keras untuk menuntut ilmu silat. Kemahiran silat merupakan tuntutan kondisi karena dimasa itu perjalanan jauh atau bepergian dari suatu nagari ke nagari yang lain hanya dapat ditempuh dengan berjalan kaki. Saat itu perjalanan banyak menghadapi halangan dan rintangan baik berasal dari binatang-binatang buas maupun berasal dari orang-orang jahat. Kesungguhan untuk belajar silat ini telah Beliau Kumango wujudkan dengan meminta berguru kepada seorang guru silat yang masyhur di zaman itu yaitu Datuk Guru dari persilatan Lintau.

Semakin hari persediaan perbekalan Beliau Kumango semakin menipis, hingga Beliau Kumango pasrah dan berniat hendak pulang kembali ke Kumango. Malam hari ketika beliau tengah tertidur, beliau bermimpi didatangi seorang tua yang menunjukkan kepada beliau tempat yang harus beliau datangi untuk belajar silat. Keesokan harinya Beliau Kumango mendatangi tempat yang dimaksud oleh seorang tua tersebut, dan terkejutlah beliau ketika dilihatnya orang tua itu telah menantinya.

Beliau Kumango akhirnya berguru silat kepada seorang tua tersebut yang bernama Sang Guru Besar. Lama berlatih silat kepada Sang Guru Besar akhirnya Beliau Kumango memutuskan kembali ke Kumango. Sesampainya di Kumango, Beliau Kumango tidak menyimpan ilmu silat yang ia pelajari itu sendiri. Beliau Kumango mengajarkan silat tersebut kepada masyarakat dan sanak saudara yang ada di Kumango, dan silat yang ia ajarkan itu dikenal dengan nama Silek Kumango, hingga saat ini. Silek Kumango diajarkan dengan pemahaman bahwa silat ini tidak untuk melawan musuh dan tidak untuk perkelahian apalagi untuk tujuan membunuh. Silek Kumango diajarkan bertujuan untuk hiburan dan pertunjukkan bagi masyarakat Kumango umumnya dan sebagai pelindung diri individu dan kelompok khususnya.

\section{Proses Pelaksanaan Silek Kumango}

Pada pelaksanaan silek secara umum mimiliki kesamaan yakni dalam hal proses, dimana diawali dengan tahapan awal, pelaksanaannya hingga akhir atau penutup dari pelaksanaan silek itu sendiri. Adapun proses pelaksanaan dalam Silek Kumango ini adalah: 


\section{Awal, Manatiang Syaraik atau Mengangkat Sumpah}

Seseorang atau setiap generasi muda yang ingin mempelajari atau mendalami Silek Kumango, maka ia harus melakukan tahapan awal yakni manatiang syaraik. Adapun syaratsyarat yang harus dibawa oleh calon murid atau calon generasi muda yang ingin mempelajari dan menekuni Silek Kumango dan diserahkan kepada guru silek yang bersangkutan ini adalah: (1) Lado (cabe) dan Garam, kepandaian yang nanti ia peroleh selama mempelajari silek kumango ini dianalogikan pedasnya seperti lado, dan asinnya garam. (2) Pisau Tumpul, dimaknai sebagai proses belajar yang diasah secara terus menerus, setelah tajam dipergunakan seperlunya, atau diartikan nantinya akan bersifat bijaksana dan tidak boleh sombong. (3) Kain Putih, sebagai simbol kepasrahan diri kepada Sang Khalik, bahwa pada dasarnya manusia akan kembali kepada-Nya, maka kain putih sebagai bungkus persiapan kapan kita dipanggil untuk menghadap-Nya. (4) Jarum dan Benang, sebagai upaya efisiensi, hemat, tidak boros, dan mempergunakan apa yang ada menjadi berguna. (5) Beras Secupak, sebagai paya mandiri, dan penyesuian tahap awal saat di perguruan, yang digunakan untuk bekal sementara. (6) Ayam Betina, sebagai upaya perbaikan gizi saat berlatih, telur ayam dikonsumsi untuk kesehatan, dan dimaknai sebagai bibit, untuk melanjutkan perjuangan silek kumango

Penyerahan syarat untuk manatiang syaraik apabila sudah diserahkan kepada guru silek maka calon anak sasian sudah sah diangkat menjadi murid dan akan diajar semua langkah dan gerak dalam Silek Kumango ini. Pada saat anak sasian telah mampu untuk menguasai semua langkah dan gerak yang diajarkan, biasanya sang guru akan membuka pintu bathin anak sasian dan mengajarkan beberapa ilmu bathin yang menjadi pendamping untuk silek lahir yang telah dikuasai. Tidak semua murid yang bisa menerima ilmu seperti ini, hanya mereka yang dianggap oleh sang guru mampu untuk menerima ilmu bathin ini lah yang diizinkan untuk menerima.

\section{Pelaksanaan, Latihan Silek Kumango}

Seorang anak sasian atau para generasi muda yang tlah sah diterima menjadi murid dalam perguruan Silek Kumango ini berhak untuk mengikuti settiap kali waktu latihan. Adapun waktu latihan itu sendiri adalah pada hari sabtu malam atau malam minggu yang dimulai setelah melaksanakan shalat isya berjamaah pada surau tempat latihan itu diadakan. Tahapan yang akan dilakukan sebelum latihan dimulai biasa ada beberapa hal, yang pertama setiap anak sasian diharuskan untuk mengikuti shalat isha berjamaah di surau, kedua setelah shalat isha dilaksanakan maka akan dilanjutkan dengan acara tausiah dan membaca alquran dalam waktu yang ditentukan. Ketiga, bila shalat, tausiah dan mengaji telah dilakukan maka baru latihan bisa dimulai, dengan didahului oleh setiap anak sasian membentuk barisan, berdoa, melakukan pemanasan atau peregangan otot-otot badan baru setelahnya mengikuti latihan silek tersebut.

\section{Akhir, Penutup Dalam Setiap Kali Latihan Silek Kumango}

Akhir atau penutup dari setiap kali latihan silek ini adalah melakkukan gerakan langkah tuo, yang kemudian diikuti dengan berdoa dan setelahnya latihan pun selesai. Adakalanya setiap selesai latihan silek saat waktu shubuh menjelang itu para anak sasian atau generasi muda tidak langsung pulang ke rumah masing-masing, ada yang beristirahat di surau sembari menunggu waktu shubuh masuk dengan saling bercerita bertukar pendapat dengan guru dan rekan-rekan seperguruannya. Hal demikian dilakukan guna untuk memupuk rasa persaudaraan yang kuat antar sesama anak sasian Silek Kumango.

\section{Gerakan-Gerakan dalam Silek Kumango}

\section{Langkah Tuo}

Gerakan ini merupakan unsur terpenting dalam silek kumango. Gerakan ini merupakan dasar dari semua gerakan yang ada. Ada satu hukum yang berlaku dalam sifat ini "mati jo langkah, hiduik jo langkah" yang artinya smua gerakan dalam silek ini baik yang menyerang, 
menangkis, mengunci dan membuka kuncian haruslah dengan langkah. Langkah tuo ini terdiri dari empat gerakan, karenanya sering juga disebut langkah ampek. Dalam langkah inilah terkandungnya roh atau jiwa tauhid yang menjadi sandaran utama dari silek kumango ini.

\section{Cakak}

Cakak terdiri dari, sambut luar dan sambut dalam. Sambut luar menggunakan langkah satu. Tangan dan siku kiri secara serentak digunakan menangkis tangan dan kaki. Sambil menurunkan posisi badan dengan sisi sebelah luar telapak tangan kiri, tangan lawan ditpis sedikit kea rah luar. Sedangkan siku kiri dipukulkan ke kaki penyerang. Sambut dalam, menggunakan langkah dua, tangan dan siku kanan keduanya menyambut dan menangkis tangan dan kaki. Tangan kanan dengan sisi telapak tangan sebelah luar menepis tangan arah keluar sedangkan siku kanan menghantam kaki lawan.

\section{Pisau}

Serangan pisau adalah serangan yang diarahkan ke perut atau dada. terdiri dari satu macam sambut dan satu pertalian., menyambut. Sambutnya menggunakan langkah satu. Tangan dengan sisi telapak tangan sebelah luar menepis pergelangan tangan yang memegang pisau sedangkan siku kiri menangkis kaki.

\section{Rambah}

Rambah adalah suatu bentuk serangan dengan senjata golok atau sejenisnya yang datang dari arah samping dengan sasaran leher sebelah kiri. Terdiri dari hanya satu amcam sambut dengan satu pertalian. Sambutnya menggunakan langkah dua. Tangan kiri dengan mnggunakan sisi luar telapak tangan menyambut tangan yang memegang golok sedangkan siku kanan digunakan untuk menangkis kaki.

\section{Cancang}

Cancang adalah semacam serangan dengan golok atau sejenisnya dari arah atas. Sasarannya adalah kepala. Sambutnya terdiri dari satu macam dan dua pertalian. Sambutnya sama dengan sambut pisau menggunakan langkah satu. Tangan kanan di sisi luar telapak tangan dari arah atas kepala menangkis tangan yang memegang golok, dibawa ke bawah arah depan bdan dan siku kiri menangkis kaki lawa

\section{Ampang}

Serangan ini sama polanya dengan cakak. Sambutnya juga dua macam, sambut luar dan dalam, masing-masing dengan dua pertalian. Sambut Luar, Sambut ini menggunakan langkah satu, pola dan geraknya sama dengan sambut pisau dan sambut dalam, pola sambut ini sama dengan sambut rambah. Tangan kiri menyambut tinju dan siku kanan menangkis kaki. Setelah lawan menarik dan menurunkan kakinya pegang pangkal telapak tangan dengan tangan kiri, tangan kanan menyerang ke rusuk lawan.

\section{Patah Tabu}

Serangan maupun sambut patah tabu ini sama polanya dengan ampang, terdiri dari sambut luar dan sambut dalam masing-masing terdiri dari dua pertalian. Sambut luar, menggunakan langkah satu. Setelah lawan menarik dan menurunkan kakinya, pegang pangkal telapak tangan dengan tangan kanan dengan menariknya kea rah belakang sedangkan sikunya dipegang dengan tangan kiri dan tekan kea rah depan. Sedangkan sambut dalam, menggunakan langkah dua. Setelah lawan menarik dan menurunkan kakinya, pegang pangkal telapak tangan dengan tangan kiri sedangkan siku lawan dipegang dengan tangan kanan. Telapak tangannya didorong kea rah luar dan sikunya ditarik ke arah dalam.

\section{Antak Siku}

Pola serangan dan pola sambut sama dengan patah tabu, terdiri dari sambut luar dan sambut dalam masing-masing dengan dua pertalian. Sambut luar menggunakan langkah satu, 
setelah lawan menarik dan mnurunkan kakinya pegang pangkal telapak tangannya dengan tangan kanan kemudian letakkan lengan kiri ke bagian bawah di atas lengan bawah lawan lalu tarik lengan lawan dengan siku mengarah ke kepalanya. Sambut dalam, menggunakan langkah dua. Setelah lawan menarik dan menurunkan kakinya, pegang pangkal telapak tangannya dengan tangan kiri. Lengan kanan bagian bawah diletakkan di atas lengan lawan bagian bawah dengan siku mengarah ke kepala lawan.

\section{Sandang}

Sambut sandang ini hanya ada satu macam dan satu pertalian. Langkah yang digunakan adalah langkah satu. Setelah lawan menarik dan menurunkan kakinya, pegang pangkal telapak tangannya dengan tangan kanan. Lengan bawah kiri letakkan di bawah lengan lawan bagian bawah berhimpitan dan lengan atas dengan sudut 90 derajat berada di bawah lengan atas lawan. Dengan menggelek ke kanan pangkal lengan kanan lawan diangkat ke atas sedang pangkal telapak tangannya ditarik ke bawah.

\section{Kabek}

Sambut kabek hanya terdiri dari satu amcam dengan dua pertalian. Langkah yang digunakan adalah langkah dua. Dengan menggeser kaki kiri sedikit ke sisi kiri sambil menggelek ke kiri, kaki kanan dimajukan dan diletakkan di sisi sebelah luar kaki kanan lawan.

\section{Ucak Tangguang}

Pada gerakan ucak tangguang ini langkahnya juga menggunakan langkah satu. Terdiri dari satu macam dan satu pertalian, setelah lawan menarik dan menurunkan kakinya, pegang telapak tangannnya dengan kedua tangan kita lalu ditarik ke bawah.

\section{Ucak Lapeh}

Pada gerakan ucak lapeh ini, sambutnya juga menggunakan langkah satu. terdiri hanya dari satu macam dan satu pertalian. seblum lawan menurunkan kakinya, tangkap pergelangan tangan dan sikunya sambil menggelek ke kanan tarik dan dorong tangan lawan.

\section{Elakan atau Tangkisan Dalam Silek Kumango dan Maknanya}

\section{Elakan atau tangkisan pertama}

Pada saat seorang musuh melakukan serangan pertama. Seorang pesilat harus menganggap serangan itu diibaratkan seorang Ibu marah pada anaknya. Artinya ketulusan yang harus dimunculkan oleh seorang pesilat adalah mengumpamakan Ibu kita sedang menasehati kita, maka kita wajib memahaminya, dan bukan melawannya, namun dalam gerakna fisik pada jurus yang diperagakan mengelaknya.

\section{Elakan atau tangkisan kedua}

Pada saat seorang musuh melakukan serangan kedua. Seorang pesilat harus menganggap serangan itu diibaratkan seorang ayah yang marah pada anaknya. Artinya ketulusan yang harus dimunculkan oleh seorang pesilat adalah mengumpamakan ayah kita sedang menasehati kita, maka kita wajib memahaminya, bukan melawannya, namun dalam gerakan fisik pada jurus diperagakan mengelaknya.

\section{Elakan atau tangkisan ketiga}

Pada saat seorang musuh melakukan serangan ketiga. Seorang pesilat harus menganggapnya serangan itu diibaratkan seorang guru marah pada kita. Artinya ketulusan yang harus dimunculkan oleh seorang pesilat adalah mengumpamakan guru kita sedang menasehati muridnya, maka kita wajib memahaminya, bukan melawannya, namun dalam gerakan fisik pada jurus yang diperagakan mengelaknya. 


\section{Elakan atau tangkisan keempat}

Pada saat seorang musuh melakukan serangan keempat. Seorang pesilat harus menganggapnya serangan itu diibaratkan saudara, teman, sahabat marah pada kita. Artinya ketulusan yang harus dimunculkan oleh seorang pesilat adalah mengumpamakan mereka sedang menasehati kita, maka kita wajib memahaminya, bukan melawannya, namun dalam gerakan fisik pada jurus yang diperagakan mengelaknya.

\section{Elakan atau tangkisan kelima}

Pada saat seorang musuh melakukan serangan kelima. Seorang pesilat wajib melawanya dengan mengunci lawan, dan itupun dilakukan untuk melumpuhkan bukan untuk mematikan lawan. Serangan tersebut diumpamakan serangan lawan yang sifat manusianya telah dihinggapi setan, sehingga kita wajib untuk menegurnya. Apabila musuh sudah menyerah maka secepatnya seorang pesilat menyelesaikan perselisihan dan sekaligus memberi maaf.

\section{Motivasi Generasi Muda Dalam Mempelajari Silek Kumango}

Silek Kumango merupakan bagian dari arus utama silek khas Minangkabau. Pada setiap gerakan terdapat beragam pesan dan ajaran budi pekerti, yang bertujuan membangun kepribadian seseorang berdasarkan nilai dan norma yang berlaku dalam masyarakat Minangkabau. Beragam motivasi anak Nagari Kumango dalam mempelajari silek dipengaruhi oleh beberapa hal yang bersumber dari dalam dirinya dan dari luar diri seseorang.

Mengacu pada teori motivasi Herzberg, mengenai motivasi yang dipengaruhi dua faktor yaitu faktor motivasional dan faktor hygiene (pemeliharaan). Faktor motivasional adalah hal-hal yang mendorong seseorang berprestasi sifatnya intrinsik (dalam diri) dan faktor hygiene yang berasal dari luar diri yang turut menentukan perilaku seseorang dalam kehidupan seseorang (Herzberg, 1959). Teori Herzberg memberikan pemahaman keterkaitan antara faktor motivasional (bersifat intrinstik) anak Nagari dalam mempelajari silek yaitu selain rasa cinta terhadap budaya, mereka berusaha untuk mencapai kepuasan, kesenangan, rasa aman dan prestasi melalui silek, sedangkan faktor hygiene (bersifat ekstristik), mereka mempelajari Silek Kumango karena adanya pengaruh lingkungan sosial. Ada lima hal yang memotivasi anak Nagari Kumango dalam mempelajari silet, diantaranya

\section{Rasa Ingin Tahu}

Adanya sikap untuk mengetahui segala hal tersebut juga menjadi salah satu alasan para generasi muda yang mempelajari Silek Kumango. Dimulai dengan rasa ingintahu dan mencoba mengenal Silek Kumango membawa mereka kepada tahapan dimana mereka harus memutuskan untuk berhenti atau tidak dalam menekuni Silek Kumango itu setelah rasa ingin tahu mereka terjawab. DV salah seorang anak sasian yang berusia 16 tahun menuturkan tentang awal mulanya ia mempelajari Silek Kumango ini:

"Saya waktu itu ikut latihan silek ini sebenarnya hanya ingin tahu saja seperti apa sebenarnya silek kumango itu. Lantas saya ikut pergi latihan dengan seorang teman saya yang memang telah lama ikut berlatih. Saya fikir kenapa tidak dicoba saja dulu, kan latihannya tidak bersifat memaksa, saya bisa masuk dan keluar nanti jika saya sudah bosan".

Lain halnya dengan FJ, FJ awalnya juga karena rasa ingin tahu saat ia duduk di bangku Sekolah Menengah Pertama memutuskan untuk mempelajari Silek Kumango ini. FJ saat ini mengakui bahwa rasa keingintahuannya dahulu terhadap silek ini menyebabkan ia mencintai silek leluhur Nagari Kumango ini, seperti yang ia ungkapkan:

"Awalnya saya ikut latihan silek dahulu karena mau tau seperti apa silek kumango itu, setelah saya pelajari ternyata saya suka, pada gerakannya yang ringan, pada 
ilmu-ilmu kebaikan yang diajarkan, makanya saya sampai sekarang masih terus rutin latihan silek ini karena saya sudah menyukai silek ini".

Adanya rasa kesenangan pada diri FJ karena menyukai gerakan-gerakan silek yang ringan menyebabkan FJ menerima segala nilai baik yang terkandung di dalam silek kumango ini.

\section{Pengaruh Lingkungan Sosial}

Pada setiap generasi muda, lingkungan sepermainan merupakan suatu hal yang selalu dikait-kaitkan dengan diri mereka. Timbulnya segala prilaku dalam diri seseseorang tidak terlepas dari dan dengan siapa di bergaul. Salah satu hal lain yang menjadi alasan seorang generasi muda yang mempelajari silek kumango ini didapat kan dari penuturan HA seorang pemuda yang berusia 22 tahun, ia mengatakan bahwa teman-teman sebayanya di lingkungan pekerjaan kebanyakan mempelajari silek kumango ini, lantas ia pun juga mengikuti hal tersebut, seperti yang ia ungkapkan saat di lapangan:

"Kawan-kawan saya di pangkalan ojek ini banyak yang ikut latihan silek di surau, karena saya juga ingin seperti mereka yang jago silek, saya akhirnya ikut bergabung latihan dengan mereka dan ternyata menyenangkan"

Pengalaman dan cerita-cerita teman sebaya mengenai silek yang memiliki gerakan-gerakan yang lincah dan ringan dan tidak hanya mengandalkan otot besar dan fisik saja, melainkan mengutamakan akal dan naluri ini lah yang menyebabkan HA ikut mempelajari silek kumango ini.

\section{Prestasi}

Seorang anak yang baru lahir akan mendapatkan pengetahuan dan sosialisasi tentang kehidupan ini pertama kali adalah melalui keluarga. Keluarga lah yang berperan paling penting dalam membentuk watak seorang anak. Baik dan buruknya sifat anak lebih didominan kan oleh campur tangan keluarga di rumah.

Informan lainnya mengatakan bahwa alasan ia mempelajari dan menekuni silek kumango ini adalah karena keinginannya sendiri dan latar belakang dari keluarganya yang memang telah menekuni silek ini sejak lama dan memiliki prestasi dibidang tersebut. Hal ini lah yang menyebabkan SZ juga ikut mempelajari dan menekuni silek kumango. SZ menuturkan:

"Beberapa orang paman saya sering bercerita tentang silek kumango ini. Cerita bagaimana mereka sering menjadi juara dalam perlombaan silek. karena keseringan dengar cerita-cerita mereka akhirnya membuat saya semangat belajar silek kumango sampai sekarang".

Seorang generasi muda yang mempelajari silek karena pengaruh dari keluarganya adalah suatu kewajaran karena mereka sudah tahu dan memiliki kepercyaaan penuh terhadap anggota keluarganya yang telah menekuni silek lebih dulu, apalagi yang juga memiliki prestasi dibidang tersebut. Baik dan buruknya segala penanaman nilai-nilai yang ada dalam silek secara tidak langsung sudah dapat mereka lihat dan mereka rasakan dari keluarganya sebelum mereka sendiri yang memutuskan untuk mempelajari silek.

\section{Rasa Cinta Kebudayaan}

Seseorang yang mempunyai alasan mempelajari silek adalah untuk mempertahankan kebudayaan leluhur mereka yang telah mulai tergerus arus modernisasi merupakan suatu hal yang patut diacungi jempol. Hal demikian dapat terjadi karena memang dalam dikri seseorang itu memiki rasa tanggung jawab yang kuat untuk menjaga dan melestarikan budaya leluhur mereka. G salah seorang informan yang duduk di bangku Sekolah Menengah Atas ini menuturkan 


\begin{abstract}
"Silek Kumango ini adalah warisan budaya asli dari orang Kumango, orang luar saja banyak yang mempelajari silek ini, kenapa saya sendiri yang asli nagari kumango ini tidak mau mempelajarinya. padahal silek ini adalah silek yang bukan bertujuan untuk dipertandingkan ataupun untuk menyakiti lawan dan kawan, tetapi lebih dari itu untuk menjaga diri dari kejahatan, untuk menyiarkan agama dan untuk pertunjukkan hiburan"
\end{abstract}

Pola fikir yang seperti itu dari dalam diri individu generasi muda mengenai warisan budaya terkhusus silek kumango dan segala nilai-nilai luhur di dalamnya yang merupakan silek tradisional anak nagari itu secara lahiriah menjadikan mereka memiliki rasa tanggung jawab yang kuat dan memiliki kecintaan yang besar pada budaya leluhur mereka untuk tetap mempertahankannya.Keinginan dan kesadaran generasi muda untuk terus dan tetap mempertahankan warisan budaya mereka menjadikan silek ini masih tetap hidup dan berkembang di nagari mereka khususnya dan di dunia luar umumnya.

Banyaknya ilmu bela diri asing yang masuk ke Indonesia tidak lantas melunturkan kecintaan mereka terhadap budaya bela diri anak nagari mereka sendiri. Kecintaan seperti itu juga didasari karena pengetahuan mereka yang menilai bahwa ilmu bela diri nagari mereka sendiri sebenarnya tidak jauh bagus dan baiknya dari ilmu bela diri asing yang berkembang di luar sana. Baik dari setiap gerakannya, sikapnya, pengajarannya hingga nilai dan fungsi yang terkandung di dalamnya.

Bagi generasi muda yang memiliki pandangan dan pemikiran luas yang menganggap segala nilai dan fungsi falsafah agama dan adat Minang Kabau yang terkandung di dalam silek anak nagari ini lebih baik dari ilmu bela diri asing akan membentuk individu mereka kepada rasa bertanggung jawab untuk tetap melestarikan silek kumango ini agar nantinya dapat diwariskan lagi kepada anak cucu mereka, seperti apa yang telah mereka terima sekarang.

\title{
Keamanan
}

Pada masyarakat Minangkabau ataupun pada Nagari Kumango khususnya merantau adalah kebiasaan yang sudah dilakukan turun temurun. Sebelum anak muda melakukan perjalanan ke tanah rantau. Orang tua atau mamak mereka telah mempersiapkan bekal sejak usia dini, seperti ilmu agama, ilmu adat, dan ilmu lainnya yang berguna sebagai pedoman hidup ditanah rantau. Silek adalah salah satu bekal yang juga diberikan sebelum anak muda nagari Kumango pergi merantau. RK salah satu informan yang memiliki keinginan untuk merantau menjelaskan,

"Silek Kumango dari dahulu sudah menjadi hal wajib untuk dipelajari oleh anak muda Nagarai Kumango, karena setelah menyelesaikan pendidikan sekolah kebanyakan anak muda dikampung kami memilih untuk meninggalkan kampung (merantau). Silek diajarkan oleh guru silek yang ada dikampung."

Alasan keamanan merupakan salah satu motivasi yang kuat dalam mempelari silek. Silek bekal anak muda minang, khusunya nagari Kumango diharapkan berguna untuk melindungi diri ketika sudah berada di perantauan nanti ataupun juga berguna untuk melindungi orang lain.

\section{Kesimpulan}

Dari pebelitian diperoleh hasil bahwa motivasi para generasi muda ingin belajar dan menekuni Silek Kumango ini adalah karena pengaruh yang bersumber dari dalam dan luar diri mereka. Silek terus diajarkan oleh guru silek kumango secara turun temurun dari generasi ke genarasi sehingga sudah menjadi bagian dalam kehidupan masyarakat. Silek memunculkan besarnya rasa keingin tahuan mereka sehingga rajin menekuninya, serta ingin memiliki prestasi dibidang tersebut. Mereka merasakan banyaknya manfaat positif mempelajari silek dalam

Culture \& Society: Journal of Anthropological Research Vol. 2, No. 3, Th. 2021 
kehidupan kesehariannya, contohnya dalam bersikap kepada orang tua dan lingkungan sepermainan. Alasan lainnya karena mereka masih memiliki kecintaan terhadap kebudayaan mereka, dan menginginkan Silek Kumango ini tetap terus berkembang hingga nantinya. Silek Kumango ini adalah aset pengenal jati diri mereka sebagai orang Kumango. silek sebagai identitas diri mereka dan sekaligus sebagai bekal untuk melindungi diri di tanah perantauan. Selain itu, generasi muda juga diajarkan cara bersikap yang baik menurut kepada agama islam dan adat Minangkabau. Seorang pesilat tidak pandai bersilat saja tetapi juga pandai dalam mengatur tingkah pola kehidupan untuk menegakkan kebenaran dan mencegah kejahatan di dalam maupun di luar lingkungan tempat tinggalnya.

\section{Daftar Pustaka}

Ahimsa-Putra, H. . (2009). Paradigma Ilmu Sosial-Budaya; Sebuah Pandangan. Makalah dalam Kuliah Umum Paradigma Penelitian Ilmu-Ilmu Humaniora Bandung. Bandung: Universitas Pendidikan Indonesia.

Danandjaja. J. (2002). Folklor Indonesia (Ilmu Gosip, Dongeng dan Lain-Lain Cet. VI. Jakarta: Pustaka Utama Grafiti.

Dhamarmulya, S. (1993). Transformasi Nilai Budaya Melalui Anak-Anak. Yogyakarta: Balai Kajian Sejaran dan Nilai Tradisional.

Herzberg, F. (1959). The Motivation to Work. USA: John Wiley \& Sons, Inc.

Koentjaraningrat, K. (1980). Sejarah Teori Antropologi I. Jakarta: UI Press.

Krisnawardi, K., \& Ismar, I. (2017). Penciptaan Koreografi "Galuik Kumango" Melalui Penelitian Artistik Terhadap Silat Minangkabau. Beranda: Jurnal Seni Pertunjukan, 6(1), 4368.

Saputra, I. (2011). Silek Kumango: Keberadaan, Pewarisan, dan Kearifan Lokal Minangkabau. Jurnal Elektronika Wacana Etnik: Jurnal Ilmu Sosial Dan Humaniora, 2(1), 73-94.

Sukri, A. (2019). Koreografi Tonggak Raso Berbasis Silek. Garak Jo Garik: Jurnal Pengkajian Dan Penciptaan Seni, 13(2), 73-94.

Sumirtarsih, S. (2008). Permainan Tradisional Jawa. Yogyakarta: Kepel Pers.

Tashadi, T. (1993). Transformasi Nilai Melalui Permainan Rakyat Daerah Istimewa Yogyakarta. Yogyakarta: Depdikbud, Dirjen Kebudayaan, Direktorat Sejarah dan Nilai Tradisional.

Yunus, A. (1980). Permainan Rakyat DIY. Yogyakarta: Depdikbud. 


\section{Daftar Istilah}

1. Dalam istilah Silek Kumango, manatiang syaraik artinya mengangkat sumpah bagi calon murid silek kumango itu sendiri

2. Dalam bahasa Minang Kabau, sacupak diartikan sebagai takaran untuk mengukur banyak beras.

3. Dalam istilah silek kumango, anak sasian diartikan sebagai murid

4. Langkah tuo adalah nama gerakan yang paling penting dan utama dalam silek kumango 